\title{
IMPACT OF PREPARATION USING CONVENTIONAL AND MODIFIED DENSITY GRADIENT CENTRIFUGATION METHODS ON SPERM CONCENTRATION, MOTILITY AND NUMBER OF NORMAL MOTILE SPERM RECOVERY (NMSR)
}

\author{
Yudiwati $\mathbf{R}^{1}$, Pramesti MPBD ${ }^{1}$, Agustinus ${ }^{1}$, Pradana $E^{1}$, Purwanto $B^{2}$ \\ ${ }^{1}$ Department of Biomedical Science, ${ }^{2}$ Department of Physiology, Faculty of Medicine, Universitas Airlangga
}

\begin{abstract}
ABSTRAK
Beberapa teknik persiapan sperma, baik konvensional maupun advance sudah tersedia. Teknik advance mampu mengatasi keterbatasan teknik konvensional. Saat ini, tidak semua klinik fertilitas di Indonesia mampu menyediakan teknik persiapan advance. Beberapa teknik memerlukan peralatan mahal dan hanya bisa digunakan untuk injeksi sperma intracytoplasmic. Beberapa klinik menggunakan prosedur yang dimodifikasi, yaitu density gradient centrifugation (DGC) dilanjutkan dengan metode swim up untuk persiapan sperma yang akan digunakan dalam Teknologi reporduksi berbantu (TRB). Penelitian ini bertujuan untuk mengetahui apakah density gradient centrifugation yang dimodifikasi, yaitu density gradient centrifugation diikuti oleh swim up, mampu memberikan hasil lebih baik daripada density gradient centrifugation konvensional. Penelitian ini merupakan penelitian eksperimental pre dan post test control group. Populasi adalah semua pria dewasa berusia 21-40 tahun dan sampel adalah pria donor yang memenuhi kriteria inklusi selama masa penelitian. Besar sampel sebanyak delapan. Analisis sperma dilakukan sebelum dan sesudah persiapan pada kelompok konvensional dan modifikasi. Digunakan analisis perbandingan deskriptif. Didapatkan

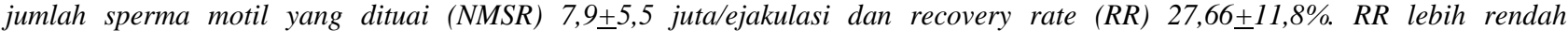
dibandingkan RR yang diperoleh metode DGC konvensional. RR lebih rendah karena sampel DGC yang dimodifikasi menjalani dua langkah seleksi sementara DGC konvensional hanya satu langkah seleksi. Namun, sampel DGC konvensional harus disentrifugasi dua kali sehingga sperma mengalami trauma lebih tinggi. RR yang rendah tidak mengecualikan kemungkinan menggunakan metode ini, karena masih dalam batas yang dibutuhkan untuk semua TRB. Sebagai kesimpulan, metode persiapan DGC yang dimodifikasi memperoleh NMSR dan RR yang lebih rendah, namun sperma yang diperoleh tetap dapat digunakan pada semua jenis TRB. (FMI 2017;53:196-198)
\end{abstract}

Kata kunci: Metode density gradient centrifugation yang dimodifikasi; recovery rate; jumlah sperma motil yang dituai

\begin{abstract}
Some preparation techniques, either conventional or advanced, have been provided. Advanced technique may overcome the limitations of conventional techniques. Recently, not all fertility clinics in Indonesia are able to provide advanced preparation techniques. Some techniques require expensive equipments and can only be used for intracytoplasmic sperm injection (ICSI). Some fertility clinics use a modified procedure, namely the combination of density gradient centrifugation with a swim-up method for the preparation of the sperm to be used in ART. This study aimed to determine whether the modified density gradient centrifugation, which is density gradient centrifugation followed by a swim-up, is able to yield better results than conventional density gradient centrifugation. This study was a laboratory experimental pre and pos-test control group design. Population was all adult men aged 21-40 years old and the sampling unit was the man donor's semen which fulfilled inclusion criterias, collected during the periode of the study. Sample size was eight. Sperm analysis were done before and after preparation in conventional and modified group. Descriptive comparation analysis have been used. This study obtained NMSR 7.9+5.5 million/ejaculate and recovery rate (RR) $27.66+11.8 \%$. RR was lower compared to RR obtained conventional DGC method. RR might be lower because in modified DGC samples undergo two steps selection while conventional DGC only one step selection. But conventional DGC samples should be centrifuged twice, therefore sperms might experience more trauma. Lower RR sperm does not exclude the possibility to be used for $A R T$, because still within the required number for all TRBs. In conclusion, modified DGC preparation method obtained lower NMSR and RR, nevertheless harvested sperms can still be used in all kind of ART. (FMI 2017;53:196-198)
\end{abstract}

Keywords: Modified density gradient centrifugation method; recovery rate; normal motile sperm recovery

Correspondence: Yudiwati R. Department of Biomedical Science, Faculty of Medicine, Airlangga University. Email: beppi2005@yahoo.com

\section{INTRODUCTION}

Sperm preparation is one of the processes required for the implementation of assisted reproduction techniques (ART). In addition to separating the spermatozoa to seminal plasma, sperm preparation also aims to obtain a good quality in terms of motility, morphology and DNA integrity. The quality of sperm preparation result is essential for the success of ART. The use of ART is 
increasing, and will be followed by an increase in sperm preparation requirements.

Some preparation techniques, either conventional or advanced has been provided (De Geyter et al 2010, Grunewald \& Paasch 2014). Advanced technique can overcome the limitations of conventional techniques. Motile sperm organelle morphology examination (MSOME) was significantly positively correlated with the number of fertilization and pregnancy (Bartoov et al 2002). Annexin-V magnetic activated cell sorting (MACS) can effectively separates nonapoptotic sperms from sperms which undergo phosphatidylserine externalization. Combination of density gradient centrifugation (DGC) with Annexin-V MACS showed good results (Said et al 2005, Said \& Agrawal 2006, Dirican et al 2008). Zeta method can briefly give better morphology, DNA integrity and aniline blue test of harvested sperms (Beydola et al 2014).

Recently, not all fertility clinics in Indonesia are able to provide advanced preparation techniques. Some techniques require expensive equipments and can only be used for intracytoplasmic sperm injection (ICSI). Today, some fertility clinics use a modified procedure which is the combination of density gradient centrifugation with a swim-up method for the preparation of the sperm to be used in ART. This modified method is supported by the results of recent studies which showed no significant differences in sperm motility, morphology, DNA integrity, and ultra structure between the results of the harvested sperm of swim-up and advanced techniques Annexin-V MACS (Curti et al 2014, Nadalini et al 2014). However, no studies have reported the concentration, number of motile sperm recovered or recovery rate of harvest sperm results of such modified method. This study aimed to determine whether the modified density gradient centrifugation, which is density gradient centrifugation followed by a swim-up, able to yield better results than conventional density gradient centrifugation.

\section{MATERIALS AND METHODS}

The design of this study was laboratory experimental pre and pos-test control group design (Pocock 2008). The population was all adult men aged 21-40 years old and the sampling unit was the man donor's semen which fulfilled inclusion criteria, collected during the period of the study. All candidates must be informed about study details and must sign the informed consent forms. Sample size was determined by a formula as cited in Madiyono et al (2011), from which obtained minimal sample size was eight.

Inclusion criteria were: adult man 21-40 years old, willing to be enrolled in the study and signed informed consent form, semen volume was $=2 \mathrm{~mL}$, total motile sperm was $>10$ millions. Exclusion criteria were: abstinence was less than 2 days or more than 7 days, hematospermia, leucocytospermia, had an experience of antisperm antibody, and positive agglutination. Sample was taken by purposive sampling method to all candidaes who had to have a sperm analysis and fulfilled inclusion criteria. The dependent variables were sperm concentration, progressive motile percentage, normal morphology percentage and normal motile sperm recovery (NMSR).

Sperm analysis were done on fresh semen samples, than samples were divided into equally two parts. One part should continue with conventional DGC, another part with modified DGC. Sperm analysis after preparation were also performed. Preparation medium used in this study was Sil-Select Plus ${ }^{\circledR}$ kit (silane coated colloidal silica particles suspension in HEPES-buffered EBSS). Sperm analysis was performed by two examiners, based on "WHO laboratory manual for the examination and processing of human semen" 5th edition, 2010. The data have been underwent descriptive analysis, normality was tested using Shapiro-Wilk Test, homogeneity was tested using Levene test and comparison was tested using paired-t or Mann-Whitney test.

Tabel 1. Pre and post-modified DGC preparation sample characteristics

\begin{tabular}{lcc}
\hline Variable & \multicolumn{2}{c}{ Value } \\
\cline { 2 - 3 } & Pre & Post \\
\hline Volume ejaculate $(\mathrm{mL})$ & $3.17 \pm 1.3$ & $0.5 \pm 0$ \\
Sperm concentration (million/ml) & $88.42 \pm 50.4$ & $18.65 \pm 11.3$ \\
Motility (\%) & & \\
$\quad$ & $37.28 \pm 14.9$ & $82.57 \pm 10.9$ \\
$\quad$ Progressive & $44.43 \pm 9.8$ & $11.83 \pm 11.7$ \\
Nonprogressive & $18.28 \pm 8.9$ & $4.28 \pm 6.8$ \\
Immotile & $34.45 \pm 27.1$ & $7.9 \pm 5.5$ (NMSR) \\
Normal motile sperm recovery & & \\
(million/ejaculate) & & \\
\hline
\end{tabular}




\section{RESULTS}

Table 1 shows seven results obtained in this study whose characteristics of pre and post modified DGC in samples preparation.

\section{DISCUSSION}

This study obtained NMSR 7.9 \pm 5.5 million/ejaculate and recovery rate $(\mathrm{RR}) 27.66+11.8 \%$. RR was lower compared to RR obtained conventional DGC method. Malvezzi reported RR were $45.3 \% \pm 18.6 \%, 48.9 \% \pm$ $18.7 \%$, and $30.8 \% \pm 17.2 \%$ respectively using conventional DGC with several different mediums. RR was lower compared to RR obtained conventional DGC method. RR might be lower because in modified DGC samples undergo two steps selection while conventional DGC only one step selection. But conventional DGC samples should be centrifuged twice, therefore sperms might experience more trauma. Lower RR sperm doesn't exclude the possibility to be used for ART, because still within the required number for all TRBs. Intra uterine insemination (IUI) is one of ART which needs relative higher number of sperms, it needs $\geq 10$ millions (Van Voorhis et al 2001). Dorjpurev et al (2011) suggested total motile sperm $\geq 5$ millions for IUI.

This study reccomends that lower number of sperm and total motile sperm still can be used for IUI, because this study did not use the whole semen volume. Higher NMSR can be obtained if whole semen volume was used. It is suggested to count total normal progressive motile sperm before preparation and to predict NMSR based on RR before deciding to use modified DGC method.

\section{CONCLUSION}

Modified DGC preparation method obtained lower NMSR and RR. Nevertheless, harvested sperms can still be used in all kind of ART.

\section{REFERENCES}

Bartoov B, Berkovcitz A, Eltes F, Kogosowski A, Menezo Y, Barak Y (2002). Real-time fine morpho- logy of motile human sperm cells is associated with IVF-ICSI outcome. J Androl, 1-8

Beydola T, Sharma RK, Agarwal A (2014). Sperm preparation and selection techniques. In : Rizk B, Aziz N, Agarwal A, Sabanegh E. (Eds). Medical and Surgical Management of Male infertility. 1st ed. New Delhi, Jaypee Brothers (P) Ltd, p 244-51

Curti G, Skowronek F, Vernochi R, Rodriguez-Buzzi AL, Rodriguez-Buzzi JC, Casanova G, Sapiro R (2014). Morphological evaluation of sperm from infertile men selected by magnetic activated cell sorting (MACS). Reproductive Biology, 289-92

De Geyter C, De Geyter M, Behre HM (2010). Assisted Reproduction. In : Nieschlag E et al. (Eds) Andrology, 3rd ed, Springer-Verlag Berlin Heidelberg, p 483-88

Dirican EK, Ozgun OD, Akarsu S, et al (2008). Clinical outcome of magnetic activated cell sorting of nonapoptotic spermatozoa before density gradient centrifugation for assisted reproduction. J Assist Reprod Genet, 375-81

Dorjpurev U, Kuwahara A, Yano Y, Taniguchi T, Yamamoto Y, Suto A, Tanaka Y, Matsuzaki T, Yasui T, Irahara M (2011). The Journal of Medical Investigation 58, 127-132

Grunewald S, Paasch U (2014). Sperm Processing and Selection. In: Parekattil SJ, Agarwal A (Eds). Male Infertility, Contemporary Clinical Approaches, Andrology, ART, \& Antioxidants, Springer New York Heidelberg Dordrecht London, p 423-30

Madiyono B, Moeslichan S, Sastroasmoro S, Budiman I, Purwanto SH (2011). Perkiraan besar sampel. In: Sastroasmoro S, Ismael S (Eds). Dasar-dasar metodologi penelitian klinis. 4th ed, Jakarta, Sagung Seto, p 348-81

Nadalini M, Tarozzi N, Di Santo M, Borini A (2014). Annexin V magnetic-activated cell sorting versus swim-up for selection of human sperm in ART: is the new approach better then the traditional one? J Assist Reprod Genet, 1045-51

Pocock SJ (2008). Clinical Trials, A Practical Approach. Cichester, John Wiley \& Sons

Said TM, Agrawal (2006). Evaluation of sperm recovery following annexin MACS. Reprod Biomed Online 13, 336-9

Said TM, Paasch U, Grunewald S, et al (2005). Advantage of combining magnetic cell separation with sperm preparation techniques. Reprod Biomed Online, 740-6 